удк 332.132

\title{
ПЕРСПЕКТИВИ СТВОРЕННЯ БІОТЕХНОЛОГІЧНОГО КЛАСТЕРА У ЛЬВІВСЬКІЙ ОБЛАСТІ
}

\section{ASPECTS OF CREATION OF A BIOTECHNOLOGICAL CLUSTER IN THE LVIV REGION}

\author{
Василюк Софрія Володимирівна \\ кандидат хімічних наук, старший науковий співробітник, \\ Національний університет «Львівська політехніка» \\ ORCID: https://orcid.org/0000-0003-2946-0513
}

\author{
Vasulyuk Sofiya \\ Lviv National Polytechnic University
}

\begin{abstract}
Обґрунтовано, що на сьогодні немає уніфрікованого механізму фрормування того чи іншого типу кластерів, що породжує потребу оцінки перспективності та раціональності створення та ефективного управління кластерами в умовах економіки України. Доведено, що з погляду інвестиційної привабливості Львівщину можна охарактеризувати як регіон з розвиненою транспортною, інженерною та соціальною інфраструктурою, високим рівнем розвитку креативної індустрії та інноваційної активності. Визначено сильні і слабкі сторони створення біотехнологічного кластера у Львівській області. Виокремлено ключові завдання даного кластера. Доведено, що формування біотехнологічного кластеру у Львівській області обумовлено закономірностями галузевого розвитку регіональної економіки і на даному етапі зароджується за умов сприятливого сполучення низки чинників, що відкриває перспективи виходу на зовнішні ринки та сприятливого клімату співпраці між суб'єктами кластера.

Ключові слова: біоекономіка, біотехнологія, регіональна економіка, розвиток продуктивних сил, біотехнологічний кластер.
\end{abstract}

Обосновано, что на сегодня нет унифицированного механизма фрормирования того или иного типа кластеров, что порождает потребность оценки перспективности и рациональности создания и управления кластерами в условиях экономики Украины. Доказано, что с точки зрения инвестиционной привлекательности Львовскую область можно охарактеризовать как регион с развитой транспортной, инженерной и социальной инфраструктурой, высоким уровнем развития креативной индустрии и инновационной активности. Определены сильные и слабые стороны создания биотехнологического кластера во Львовской области. Выделены ключевые задачи данного кластера. Доказано, что фоормирование биотехнологического кластера во Львовской области обусловлено закономерностями отраслевого развития региональной экономики и на данном этапе зарождается в условиях благоприятного сочетания ряда фракторов, открывает перспективы выхода на внешние рынки и благоприятного климата сотрудничества между субъектами кластера.

Ключевые слова: биоэкономика, биотехнология, региональная экономика, развитие производительных сил, биотехнологический кластер.

It is substantiated that today there is no unified mechanism for the formation of one or another type of clusters, which creates the need to assess the prospects and rationality of the creation and effective management of clusters in the Ukrainian economy. It is determined that most publications reveal some aspects of cluster formation (for example, preconditions for merging regional enterprises into a regional cluster) or the results of existing cluster formations focusing on the successful experience of the most progressive ones (biotechnology clusters in Silicon Valley, Boston, UK, Germany France or China), so the study of the possibility of forming and developing technological (including biotechnological) clusters, especially in the economy of Ukraine, remains relevant. It is proved that from the point of view of investment attractiveness Lviv region can be characterized as a region with developed transport, engineering and social infrastructure, high level of development of creative industry and innovation activity, which is endowed with significant natural and recreational resources and landscape diversity. Due to the favorable geographical location in the region, an intensive policy of integration into the world economy is pursued by establishing foreign economic relations and attracting various forms of international cooperation. It is substantiated that in order to ensure sustainable development of the studied region there is a need to attract incentives for investment in innovation and technological processes, in the development of innovation infrastructure (information centers, technology parks, 
business incubators, innovation clusters, venture funds), which will increase competitiveness. on an innovative basis. Taking into account the research and innovation potential of Lviv region, the development of the necessary infrastructure, the potential of related industries, etc., we can identify certain areas of specialization of the region that will ensure its sustainable development. One of such areas is the development of the region's bioeconomy. The strengths and weaknesses of the creation of a biotechnology cluster in the Lviv region have been identified. The key tasks of this cluster are highlighted. It is proved that the formation of a biotechnology cluster in Lviv region is due to the laws of sectoral development of the regional economy and at this stage arises under a favorable combination of a number of factors: strong scientific and technological potential, necessary bioresources, skilled labor, communication and information technology, benefits which opens the prospects for entering foreign markets and a favorable climate of cooperation between the cluster.

Keywords: bioeconomics, biotechnology, regional economy, development of productive forces, biotechnological cluster.

Постановка проблеми. Формування інноваційних кластерів з кожним роком привертає до себе дедалі більше уваги як закордоном так і в Україні, оскільки модернізація економіки шляхом кластеризації $€$ ефективним інструментом, що сприяє соціально-економічного розвитку регіонів. Долаючи сучасні виклики щодо постійно наростаючої конкуренції формування кластерів дозволяє їх учасникам об'єднати свої зусилля та наявні ресурси задля забезпечення найвищої економічної ефрективності через продукування нових продуктів, отримання доступу до нових технологій чи ринків.

Слід процитувати влучне визначення С. Соколенка [1], який зазначає, що «результатом діяльності кластеру є дифузія інноваційної активності від одного учасника до іншого, тому кластери, як інноваційні джерела, стають тією основою, на якій фрормується національна інноваційна система. Автор також стверджує, що кластери попри вирішення певних галузевих завдань сприяють рівномірності та збалансованості просторового розвитку шляхом розподілу інноваційності по території регіону.

На сьогодні немає уніфрікованого механізму формування того чи іншого типу кластерів, що породжує потребу оцінки перспективності та раціональності створення та ефрективного управління кластерами в умовах економіки України.

Аналіз останніх досліджень і публікацій. Дослідженню різного роду питань пов'язаних 3 формуванням кластерів присвячені роботи цілої низки вітчизняних та зарубіжних вчених, серед яких А. І. Бірюков, Р. Бревс, Ю. Л. Владимиров, Д. Герцберг, М. В. Драпалюк, М. В. Дракін, Я. Дрожджал, К. Д. Закарья, М. Кірхер, І. Міткалік, М. Портер, Т. Пуліна, С. І. Соколенко, А. Таден, В. П. Третьяк, Л. І. Федулова, Т. В. Цихан та ін. [2-5].

Більшість публікацій розкривають окремі аспекти фрормування кластерів (наприклад, передумови об'єднання підприємств регіону в регіональний кластер) чи результати діяльності вже існуючих кластерних утворень зосереджуючи увагу на успішному досвіді найпрогресивніших 3 них (біотехнологічні кластери Силіконової долини, Бостона, Великобританії, Німеччини, Франції чи Китаю), тому дослідження можливості формування та розбудови технологічних (зокрема біотехнологічних) кластерів, особливо в умовах економіки України, залишаються досі актуальними.

Формулювання цілей статті (постановка завдання). Обґрунтувати економічну доцільність, шляхи та перспективи створення біотехнологічного кластера у Львівській області

Виклад основного матеріалу дослідження. 3 погляду інвестиційної привабливості Львівщину можна охарактеризувати як регіон 3 розвиненою транспортною, інженерною та соціальною інсрраструктурою, високим рівнем розвитку креативної індустрії та інноваційної активності, який наділений значними природними і рекреаційними ресурсами та ландшастним різноманіттям. Завдяки вигідному географрічному положенню в регіоні провадиться інтенсивна політика інтеграції у світову економіку шляхом налагодження зовнішньоекономічних зв'язків та залученню різних фрорм міжнародного співробітництва.

Щодо інвестиційної привабливості, то Львівська область займає передові позиції серед регіонів України. Зокрема, у 2018 році за показниками інвестиційної активності і соціально-економічного ефекту від інвестицій Львівщина по Україні поступилась лише Київській області.

Розбудова конкурентоспроможної економіки $€$ неможливою без залучення якісної науково-технічної бази та фрормування тісних взаємозв'язків між наукою та виробництвом, які будуть пришвидшувати впровадження наукових досліджень та відкривати шлях новітнім технологіям. Науковий потенціал Львівської 
області є доволі потужним. За чисельністю наукових організацій регіон посідає третє місце по Україні. Упродовж 2019 року кількість організацій, які здійснювали НДР у області становила 69 організацій, а до їх виконання було залучено 4155 працівників, з яких 3140 дослідники, 227 - техніки, 788 - допоміжний персонал. Частка дослідників Львівської області в 2019p. становила 6,14\% від їх кількості в Україні [6].

щодо загального обсягу фрінансування НДР, то у 2019 році на виконання наукових досліджень і розробок, що провадились в регіоні відводилось 465,5 млн грн, 3 яких 122,9 млн грн на науково-технічні розробки [6].

Попри потужний науковий потенціал, розвинуту науково-освітньою інфрраструктуру та високий рівень освіченості населення в області існують і певні проблеми пов'язані зокрема 3 недостатнім рівнем інтегрованості науки, освіти та реального сектору економіки, відтоком цінних кваліфрікованих наукових і технічних кадрів, низькою зацікавленістю підприємців вітчизняними перспективними розробками, що веде до знецінення останніх. Забезпечення сталого розвитку досліджуваного регіону потребує залучення стимулюючих механізмів інвестування в інноваційно-технологічні процеси, в розбудову інноваційної інсрраструктури (інформаційних центрів, технопарків, бізнес-інкубаторів, інноваційних кластерів, венчурних фрондів), які будуть сприяти підвищенню конкурентоспроможності економіки реґіону на інноваційних засадах.

На сьогодні підвищення конкурентоспроможності економіки за допомогою кластерних ініціатив можна простежити в стратегіях розвитку більшості держав. Формування кластерів в регіональній економіці результує ефективним поєднанням зусиль держави, бізнесу та науки в розвитку регіону, оскільки в структурі промислового кластера $€$ державні та приватні зацікавлені суб'єкти, які здійснюють взаємодію, координують діяльність та співпрацюють у спільних дослідженнях, розробках та комерційних проектах. Забезпечивши якісне управління кластером можна досягти фрормування цілеспрямованих та необмежених комунікаційних платфрорм, які будуть підґрунтям для створення відкритого інноваційного клімату. При цьому основне завдання управління кластером для цілеспрямовано його розвитку полягає у забезпеченні координації та комунікації в складного процесу в якому науково-дослідні установи зацікавлені темами перспективними для певної галузі, галузь цікавиться новітніми розробками та має намір їх впроваджувати, інвестори детально розробляють оцінку нових технологій, а державне управління адаптує державну інорраструктуру.

М. Кірхер з колегами у своїй роботі виокремили три базові умови для фрормування успішного кластеру [7]:

- Спільне бачення (Спільний погляд на цілі та стратегію кластера, який враховує різні інтереси зацікавлених сторін дозволяє перетворити ці зацікавлені сторони на справжні члени кластеру, тому прагнення збалансованої участі усіх зацікавлених сторін $€$ вирішальним елементом управління кластерами).

- Культура співпраці (Формально кластер складається $з$ компаній, державних та наукових інститутів. Однак важливими $є$ особи, які створюють клімат співпраці шляхом серйозного та довірливого спілкування. Саме це загальне розуміння дає змогу обмінюватися ідеями та пропозиціями при одночасному дотриманні індивідуальних інтересів перед тим, як розпочати офріційні переговори під конфріденційністю. Створення такої культури та клімату співпраці - ще один ключовий елемент управління кластерами).

- Активні члени (Жодна кластерна стратегія не може бути реалізована без активних членів, які в свою чергу будуть активні роль лише коли відчують справжню вигоду для своєї організації. Тому керівництву кластером завжди доцільно ретельно аналізує вимоги та потреби членів. Орієнтації управління кластером на інтереси членів та на узгоджену спільну стратегію кластеру може сприяти фрінансування за рахунок членства, оскільки членські внески будуть заохочувати представників організацій-членів брати активну участь шляхом обміну досвідом та ідеями чи участі розробці та виконанні проектів).

Беручи до уваги науково-дослідний та інноваційний потенціал Львівської області, розвиненість необхідної інфрраструктури, потенціал суміжних галузей, тощо, можна виокремити певні напрями спеціалізації регіону, що будуть забезпечувати його сталий розвиток. Одним із таких напрямів $€$ розвиток біоекономіки регіону.

Аналізуючи численні визначення біоекономіки можна простежити, що вона охоплює ті частини економіки, які використовують відновлювані біологічні ресурси із суші та моря (посіви, ліси, риба, тварини та мікроорганізми) для виробництва їжі, здоров'я, матеріалів, продуктів, текстилю та енергії [8]. 
Виходячи 3 наведеного твердження до основних галузей біоекономіки Львівської області можна віднести деревообробну та меблеву промисловість, поліграфрію, харчова промисловість, органічне сільське господарство, біоенергетику та біотехнології. Водночас, варто зазначити, що на сьогодні значні обсяги біоресурсів області не обліковуються та не мають єдиного координаційного центру.

Львівська область потребує розроблення стратегії розвитку біоекономіки, оскільки це $є$ надзвичайно важливим з огляду на перспективний розвиток регіону в контексті існуючої стратегії його розвитку (Стратегія розвитку Львівської області на період до 2027 року). Прогрес біоекономіки у Львівській області підтримується Радою лісового сектору при Львівській обласній державній адміністрації.

У жовтні 2018 р. розпочав свою діяльність проект POWER4BIO спрямований на підтримку регіонів, які не користуються повною мірою своїм потенціалом в отриманні продуктів сталого розвитку замість використання ресурсів на основі викопних джерел, у стимулюванні біоекономіки та аналіз такої трансорормації, виходячи 3 позицій реальних дій та конкурентоспроможності Основними учасником у цьому проекті від України став Національний лісотехнічний університет України, який працює над розробленням стратегії розвитку біоекономіки Львівської області у партнерстві з Радою лісового сектору при Львівській обласній державній адміністрації, Львівським обласним управлінням лісового та мисливського господарства, ГО «Асоціація деревообробників та лісозаготівельників Львівщини», Асоціацією «Кластер «Деревообробна індустрія», ГО «ФОРЗА». Промислові та дослідницькі партнери працюють разом, щоб об'єднати лісове господарство, лісозаготівельну та деревообробну промисловість, сільське та рибне господарство, харчову промисловість у стратегічний біоекономічний сектор розвитку регіону [9].

До пріоритетних галузей біоекономіки належать біотехнології тому доцільно приділити увагу можливості створення у регіоні біотехнологічного кластера.

Говорячи про біотехнології зазвичай під цим терміном розуміють промислове виробництво будь-якого продукту, що безпосередньо використовує молекулярно-біологічні (насамперед молекулярно-генетичні) процеси. Вказані технології найчастіше застосовують у сільському господарстві, фрармацевтичній промисловості, медицині. Щодо виробництва харчового спирту, пива, вина, дріжджів, молочних продуктів, які теж можна вважати біотехнологічними продуктами, то їх традиційно відносять до продуктів харчової промисловості [10].

3 метою оцінки перспективності створення такого кластера нами проведено SWOTаналіз, що виявляє сильні сторони та загрози при його створенні (табл. 1).

Основною метою діяльності біотехнологічного кластера $€$ фрормування умов для зростання і підвищення конкурентоспроможності компанії та установ Львівської області, діяльність яких дотична до біотехнологій.

Перед кластером постане також необхідність у вирішення низки завдань:

- перетворення біотехнологій в ефрективний ресурс для забезпечення сталого розвитку Львівської області;

- зменшення залежності від викопних ресурсів шляхом сприяння реструктуризації виробництва енергії та продовольства;

- розвиток біотехнологічних виробництв та впровадження новітніх технологій 3 урахуванням природно-кліматичних і специорічних соціально-економічних умов Львівської області;

- створення робочих місць як в містах, так і в сільських територіях;

- використання поновлюваних джерел біоресурсів забезпечуючи зниження шкідливого впливу на навколишнє середовище.

Беручи до уваги перспективність розвитку біотехнологій у Львові в листопаді 2018р вісімнадцять учасників (компанії, громадські організації, університети, науково-дослідні та навчальні установи, міська влада) підписали меморандум про співпрацю та наміри створити біотехнологічний кластер «Біотех і Фарма», який сприятиме розвитку науководослідницької та інноваційної діяльності у галузі біотехнологій у Львові, реалізації біотехнологічних бізнес-проектів, створенню нових кваліфрікованих робочих місць, економічному розвитку міста і залученню іноземних інвестицій. Зокрема, учасниками стали ПрАТ «Компанія Ензим», ТзОВ «Експлоджен», ТОВ «ХЕМА», ПрАТ «Львівський облрибкомбінат», ТзОВ «Новації. Досягнення. Лідерство.-груп», ГО «Теch Startup School», Громадська Спілка «Центр Інновацій «Сходи в Майбутнє», ГО «Українське лікарське товариство у Львові», Львівський національний університет ім. Івана Франка, Національний університет «Львівська політехніка», Львівський національний медичний універси- 
Таблиця 1

SWOT-аналіз можливості створення біотехнологічного кластера у Львівській області

\begin{tabular}{|c|c|}
\hline Сильні сторони & Слабкі сторони \\
\hline $\begin{array}{l}\text { 1. Вигідне розташування - поблизу регіонів, } \\
\text { де активно просуваються стратегії розвитку } \\
\text { біоекономіки (країни ЄС) корисний досвід яких } \\
\text { можна запозичити для адаптації до місцевих реалій. } \\
\text { 2. Наявність біоресурсів та першочергова } \\
\text { орієнтація на місцеву сировину. } \\
\text { 3. Висока якість продукції на біологічній основі } \\
\text { та відносно низькі ціни на неї. } \\
\text { 4. Високий рівень репутації компаній } \\
\text { орієнтованих на біоресурси на цільових ринках. } \\
\text { 5. Належний рівень дорожньо-транспортної, } \\
\text { транзитної та логістичної інфраструктури. } \\
\text { 6. Високий рівень освіченості економічно } \\
\text { активного населення. } \\
\text { 7. Потужна науково-освітня база. } \\
\text { 8. Розвинена інфраструктура підтримки } \\
\text { підприємництва, ефективна співпраця влади } \\
\text { 3 бізнесом, активне підприємницьке середовище } \\
\text { та високий рівень обізнаності і готовності до } \\
\text { новаторства та фрормування галузевих кластерів. } \\
\text { 9. Позитивна динаміка для розвитку } \\
\text { відновлювальної енергетики та використання } \\
\text { відновлювальних ресурсів. }\end{array}$ & $\begin{array}{l}\text { 1. Висока якість продуктів конкурентних } \\
\text { іноземних компаній. } \\
\text { 2. Низький рівень захисту інтелектуальної } \\
\text { власності, особливо міжнародного. } \\
\text { 3. Високий рівень зовнішньої міграції } \\
\text { та депопуляції сільського населення, } \\
\text { зокрема у гірських та територіально } \\
\text { віддалених від обласного центру районах. } \\
\text { 4. Відсутність належного рівня } \\
\text { маркетингової політики. } \\
\text { 5. Відносно нижча (особливо у гірських } \\
\text { територіях) природна продуктивність } \\
\text { земельних ресурсів. } \\
\text { 6. Недостатній рівень інтегрованості науки } \\
\text { та реального сектору економіки. } \\
\text { 7. Обмеженість доступу до кредитних } \\
\text { ресурсів для бізнесу та наявність } \\
\text { нетарифних бар'єрів при експорті } \\
\text { продукції місцевих товаровиробників. }\end{array}$ \\
\hline зості & $3 \mathbf{a}$ \\
\hline $\begin{array}{l}\text { 1. Підвищення інвестиційної привабливості } \\
\text { регіону та покращення його бізнес-клімату. } \\
\text { 2. Розвиток державних програм з підтримки } \\
\text { реалізації продукції біотехнологічного сектора. } \\
\text { 3. Зростання попиту на біотехнологічну } \\
\text { продукцію (зокрема органічного сільського } \\
\text { господарства), харчової промисловості. } \\
\text { 4. Наближення стандартів якості продукції, } \\
\text { виробленої в реґіоні, до міжнародних стандартів. } \\
\text { 5. Підвищення енергоесективності виробництва. } \\
\text { 6. Диверсифрікація та нарощення потенціалу } \\
\text { відновлювальної енергетики. } \\
\text { 7. Розвиток сфери прикладних наукових } \\
\text { досліджень та впровадження інновацій. } \\
\text { 8. Розвиток сільської місцевості. } \\
\text { 9. Реалізація заходів з розвитку гірських } \\
\text { територій, зокрема диверсифрікація їх економіки, } \\
\text { розвиток інорраструктури. }\end{array}$ & $\begin{array}{l}\text { 1. Загострення ситуації на ринку за } \\
\text { рахунок демпфірування цін конкурентами. } \\
\text { 2. Економічні бар'єри на національному } \\
\text { ринку. } \\
\text { 3. Погіршення ситуації через тінізацію } \\
\text { економіки. } \\
\text { 4. Низький рівень інвестування в } \\
\text { інноваційні процеси та дослідницьку } \\
\text { діяльність підприємств, що виступатиме } \\
\text { стримуючим фрактором розвитку кластера. } \\
\text { 5. Торгівельні обмеження для продукції } \\
\text { вітчизняного виробництва з боку основних } \\
\text { міжнародних партнерів. } \\
\text { 6. Посилення фріскального тиску на } \\
\text { підприємництво. } \\
\text { 7. Зниження купівельної спроможності } \\
\text { населення. } \\
\text { 8. Посилення міграції та відтік трудових } \\
\text { кадрів закордон, зокрема, найбільш } \\
\text { високоосвічених. }\end{array}$ \\
\hline
\end{tabular}

тет ім. Данила Галицького, Львівський національний університет ветеринарної медицини та біотехнологій ім. С. 3. Гжицького, Державний науково-дослідний контрольний інститут ветеринарних препаратів та кормових добавок, Інститут біології клітини НАН України, Інститут біології тварин НАН України, Львівський міський дитячий еколого-натуралістичний центр, Львівський фрізико-математичний ліцей-інтернат при ЛНУ імені І. Франка та Львівська міська рада. Зараз триває активна робота над залученням до кластеру нових учасників (компанії та установи, які розташовані на території України, діяльність яких дотична до біотехнологій), фрормуванням бази наявного обладнання, технологій, послуг, можливостей учасників біотехнологічного кластеру, облаштуванням навчального класу біотехнологічного напрямку для учнів загальноосвітніх шкіл, обговоренням бачення та налагодження співпраці щодо облаштування науково-дослідної лабораторії для науковців та студентів, перейняттям досвіду діяльності біотехнологічних кластерів Європи тощо [11]. 
Висновки. Таким чином, фрормування біотехнологічного кластеру у Львівській області обумовлено закономірностями галузевого розвитку регіональної економіки і на даному етапі зароджується за умов сприятливого сполучення низки чинників: наявності потужного науково- технологічного потенціалу, необхідних біоресурсів, кваліфрікованої робочої сили, розвиненості комунікаційних та інсрормаційних технологій, вигідного розташування, що відкриває перспективи виходу на зовнішні ринки та сприятливого клімату співпраці між суб'єктами кластера.

\section{СПИСОК ВИКОРИСТАНИХ ДЖЕРЕЛ:}

1. Соколенко С.І. Особливості розвитку екологічно чистого виробництва на основі інноваційних кластерів // Всеукраїнська науково-практична конференція «Екологічно чисте виробництво - основа підвищення якості продукції на товарних ринках України», (м. Рівне, 19 вересня 2013 р.). URL: https://ucluster.org/blog/2013/09/ osoblivosti-rozvitku-ekologichno-chistogo-virobnictva-na-osnovi-innovacijjnikh-klasteriv

2. Бирюков А.И. Формирование инновационных кластеров в высокотехнологичных отраслях промышленности (на примере АПК России) : авторефр. дис. на получение степени докт. эконом. наук : спец. 08.00.05 «Экономика и управление народным хозяйством»]. Москва, 2007. 40 с.

3. Драпалюк М.В., Дракин М.В. Перспективы создания регионального кластера биотехнологий в Воронежской области. Лесотехнический журнал (Менеджмент. Экономика. Организация). Воронеж : «ВГлУ им. Г.Ф. Морозова», 2014. № 4. С. 206-212.

4. Пуліна Т.В. Генезис кластерних об'єднань підприємств. Проблеми економіки. 2013. № 3. С. 134-142.

5. Третяк В.П. Кластеры предприятий : монограсия. Москва : «Новость», 2006. 132 с.

6. Статистичний збірник «Наукова та інноваційна діяльність України». 2019. URL: htps://ukrstat.org/en/druk/ publicat/kat_u/2020/zb/09/zb_nauka_2019.pdf

7. Kircher M., Breves R., Taden A., Herzberg D. How to capture the bioeconomy's industrial and regional potential through professional cluster management. New Biotechnology. V. 40. Part A. 25 January 2018. P. 119-128.

8. Innovating for sustainable growth: a bioeconomy for Europe. European Union. European Commission. Directorate-General for Research and Innovation. Luxembourg: Publications Office of the European Union. 2012. URL: http://www.worldcat.org/oclc/839878465

9. Beusch C., Jiménez I.-M. Розширення прав та можливостей регіональних зацікавлених сторін для реалізації всього потенціалу європейської БІО-економіки. Науково-дослідний проект. URL: https://power4bio.eu/ wp-content/uploads/2020/02/POWER4BIO_brochure_Ukrainian.pdf

10. Новіков В., Сидоров Ю., Швед О. Тенденції розвитку комерційної біотехнології. Вісник НАН України. 2008. № 2. C. 25-39.

11.У Львові створять біотехнологічний кластер «Біотех і Фарма». Львівська міська рада. URL: https://city-adm.Iviv.ua/news/society/public-sector/257547-u-lvovi-stvoriat-biotekhnolohichnyi-klaster-biotekh-i-farma

\section{REFERENCES:}

1. Sokolenko S.I. Osoblyvosti rozvytku ekolohichno chystoho vyrobnytstva na osnovi innovatsiynykh klasteriv [Features of the development of environmentally friendly production on the basis of innovation clusters]. Vseukrayins'ka naukovo-praktychna konferentsiya «Ekolohichno chyste vyrobnytstvo - osnova pidvyshchennya yakosti produktsiyi na tovarnykh rynkakh Ukrayiny», (m. Rivne, 19 veresnya 2013 r.). URL: https://ucluster.org/blog/2013/09/ osoblivosti-rozvitku-ekologichno-chistogo-virobnictva-na-osnovi-innovacijjnikh-klasteriv

2. Byryukov A.Y. (2007) Formyrovanye ynnovatsyonnykh klasterov $v$ vysokotekhnolohychnykh otraslyakh promyshlennosty (na prymere APK Rossyy) [Formation of innovation clusters in high-tech industries (on the example of Russia's agro-industrial complex)]: avtoref. dys. na poluchenye stepeny dokt. ékonom. nauk: spets. 08.00.05 «Ekonomyka y upravlenye narodnym khozyaystvom»]. Moskva, $40 \mathrm{p}$.

3. Drapalyuk M.V., Drakyn M.V. (2014) Perspektyvy sozdanyya rehyonal'noho klastera byotekhnolohyy v Voronezhskoy oblasty [Prospects for the creation of a regional cluster of biotechnology in the Voronezh region]. Lesotekhnycheskyy zhurnal (Menedzhment. Ekonomyka. Orhanyzatsyya). Voronezh: «VHLU ym. H.F. Morozova», no. 4, pp. 206-212.

4. Pulina T.V. (2013) Henezys klasternykh obyednan pidpryyemstv [Genesis of cluster associations of enterprises]. Problemy ekonomiky, no. 3, pp. 134-142.

5. Tretyak V.P. (2006) Klastery predpryyatyy [Clusters of enterprises]: monohrafyya. Moscow: «Novost'», $132 \mathrm{p}$.

6. Statystychnyy zbirnyk "Naukova ta innovatsiyna diyal'nist' Ukrayiny" (2019). URL: htps://ukrstat.org/en/druk/ publicat/kat_u/2020/zb/09/zb_nauka_2019.pdf 
7. Kircher M., Breves R., Taden A., Herzberg D. How to capture the bioeconomy"s industrial and regional potential through professional cluster management. New Biotechnology, v. 40, part A, 25 January 2018, pp. 119-128

8. Innovating for sustainable growth: a bioeconomy for Europe. European Union. European Commission. Directorate-General for Research and Innovation. Luxembourg: Publications Office of the European Union. 2012. URL: http://www.worldcat.org/oclc/839878465

9. Beusch C., Jiménez I-M. Rozshyrennya prav ta mozhlyvostey rehional'nykh zatsikavlenykh storin dlya realizatsiyi vs'oho potentsialu yevropeys'koyi BIO-ekonomiky. Naukovo-doslidnyy proekt. URL: https://power4bio.eu/ wp-content/uploads/2020/02/POWER4BIO_brochure_Ukrainian.pdf

10. Novikov V., Sydorov YU., Shved O. (2008) Tendentsiyi rozvytku komertsiynoyi biotekhnolohiyi. [Trends in the development of commercial biotechnology]. Visnyk NAN Ukrayiny, no. 2, pp. 25-39.

11. U Lvovi stvoryat biotekhnolohichnyy klaster «Biotekh i Farma». L'vivs'ka mis'ka rada. URL: https://city-adm.lviv.ua/ news/society/public-sector/257547-u-Ivovi-stvoriat-biotekhnolohichnyi-klaster-biotekh-i-farma 